\title{
EVALUASI IN VITRO AKTIVITAS ANTIBAKTERI EKSTRAK ETANOL DAUN SELADA AIR (Nasturtium officinale) TERHADAP BAKTERI METHICILLIN-RESISTANT Staphylococcus aureus
}

\author{
Aleyda Zahratunany Insanitaqwa ${ }^{\star 凶}$, Noorhamdani SS $^{\star *}$, Nugrahanti Prasetyorini ${ }^{\star \star *}$
}

\begin{abstract}
Abstrak
Methicillin-resistant Staphylococcus aureus (MRSA) adalah bakteri patogen penyebab infeksi nosokomial yang dapat menyerang beberapa sistem organ dan bersifat resisten terhadap beberapa antibiotik beta laktam seperti penisilin, sepalosporin, dan karbapenem. Prevalensi infeksi Staphylococcus aureus terus meningkat seiring dengan banyaknya prevalensi infeksi nosokomial dan meningkatnya tingkat resistensi Staphylococcus aureus terhadap beberapa antimikroba sehingga dibutuhkan suatu alternatif terapi yang dapat menggantikan atau meningkatkan efektivitas kerja antibakteri yang sudah ada. Ekstrak etanol daun selada air mengandung flavonoid, tannin, saponin, dan steroid yang dapat berperan sebagai antibakteri. Penelitian ini bertujuan untuk mengetahui aktivitas antibakteri pada ekstrak etanol daun selada air (Nasturtium officinale) terhadap MRSA secara in vitro. Rancangan penelitian yang digunakan adalah experimental post test only control group design dengan metode uji aktivitas antibakteri difusi sumuran. Ekstrak etanol daun selada air yang digunakan yaitu ekstrak dengan konsentrasi $30 \%, 60 \%, 75 \%, 90 \%$, $100 \%$, dan $0 \%$ sebagai kontrol negatif dengan pengulangan sebanyak empat kali. Hasil penelitian menunjukkan perbedaan yang signifikan $(p=0,000)$ dengan diameter zona hambat terbesar dicapai pada aplikasi konsentrasi ekstrak 100\% yaitu 9,88 $\pm 0,27 \mathrm{~mm}$, diikuti dengan konsentrasi ekstrak $90 \%$ sebesar $8,97 \pm 0,21 \mathrm{~mm}$, konsentrasi ekstrak $75 \%$ sebesar $7,90 \pm 0,61 \mathrm{~mm}$, konsentrasi ekstrak $60 \%$ sebesar $7,19 \pm 0,13 \mathrm{~mm}$, dan konsentrasi ekstrak $30 \%$ sebesar $6,16 \pm 0,12 \mathrm{~mm}$. Oleh karena itu, dapat disimpulkan bahwa ekstrak etanol daun selada air memiliki aktivitas antibakteri terhadap MRSA secara in vitro.
\end{abstract}

Kata kunci: antibakteri, daun selada air (Nasturtium officinale), methicillin-resistant Staphylococcus aureus

\section{IN VITRO EVALUATION OF ANTIBACTERIAL ACTIVITY OF WATERCRESS LEAF (Nasturtium officinale) ETHANOL EXTRACT AGAINST METHICILLIN-RESISTANT Staphylococcus aureus}

\begin{abstract}
Methicillin-resistant Staphylococcus aureus (MRSA) is pathogenic bacteria that cause nosocomial infections in multiple organs and is resistant to beta-lactam antibiotics including penicillins, cephalosporins, and carbapenems. The high prevalence of Staphylococcus aureus infection is associated with a high rate of nosocomial infection and resistance of $S$. aureus to several antimicrobial agents. Therefore, an alternative therapy that could substitute or enhance the effectiveness of remaining antimicrobial agents is needed. Watercress leaves contain flavonoids, tannins, saponins, and steroids which are proven to have antibacterial activity. This in vitro study aims to determine the antibacterial activity of watercress (Nasturtium officinale) leaves ethanol extract against MRSA. The design study used was experimental post-test only control group design and the method used was well diffusion. This study evaluated an ethanol extract of watercress leaves in six different concentrations, which are $30 \%, 60 \%, 75 \%, 90 \%, 100 \%$, and $0 \%$ as a negative control group in four times of repetition. The result showed a significant difference $(p=0.000)$ with the largest diameter of inhibition zone was observed at a concentration of $100 \%$ extract in $9.88 \pm 0.27 \mathrm{~mm}$, followed by $90 \%$ extract in $8.97 \pm 0.21 \mathrm{~mm}, 75 \%$ extract in $7.90 \pm 0.61 \mathrm{~mm}, 60 \%$ extract in $7.19 \pm 0.13 \mathrm{~mm}$, and $30 \%$ extract in $6.16 \pm 0.12 \mathrm{~mm}$. It can be concluded that watercress leaves ethanol extract has in vitro antibacterial activity against MRSA.
\end{abstract}

Keywords: antibacterial agent, methicillin-resistant Staphylococcus aureus, watercress' leaves (Nasturtium officinale)

${ }^{*}$ Program Studi Pendidikan Dokter, Fakultas Kedokteran, Universitas Brawijaya

"Departemen Mikrobiologi, Fakultas Kedokteran, Universitas Brawijaya

*** Departemen Obstetri dan Ginekologi, Fakultas Kedokteran, Universitas Brawijaya

$\bowtie$ E-mail: aleydazahra@gmail.com 


\section{Pendahuluan}

Staphylococcus aureus didefinisikan sebagai bakteri kokus Gram positif yang membentuk koloni seperti anggur dan dapat bersifat patogen pada individu yang rentan. Bakteri ini mampu menghasilkan toksin dan enzim ekstraseluler, menghancurkan sel darah, dan menggumpalkan plasma. ${ }^{1}$ Prevalensi infeksi $S$. aureus meningkat seiring dengan banyaknya prevalensi infeksi nosokomial dan meningkatnya tingkat resistensi $S$. aureus terhadap beberapa antimikroba. ${ }^{2}$ Salah satu galur $S$. aureus yang sudah mengalami resistensi yaitu methicillinresistant Staphyloccus aureus (MRSA). Pada tahun 2010, Asia merupakan benua dengan prevalensi tertinggi infeksi nosokomial akibat MRSA. ${ }^{3}$ Penelitian lain menunjukkan bahwa pada tahun $2012,45,3 \%$ dari total isolat di RSUD dr. Saiful Anwar Malang merupakan MRSA. ${ }^{4}$ Hal ini berkaitan dengan peningkatan prevalensi infeksi nosokomial atau hospitalassociated infections (HAls) dan penggunaan antimikroba yang tidak rasional. ${ }^{4}$

Mekanisme resistensi bakteri MRSA diperankan oleh gen mecA yang mengkode penicillin-binding protein 2a (PBP 2a) sehingga bakteri memiliki afinitas rendah terhadap antimikroba betalaktam, seperti golongan penisilin, sepalosporin, dan karbapenem. ${ }^{1}$ Selama ini, terapi farmakologis infeksi MRSA dapat menggunakan antibiotik vankomisin atau kombinasi kuinupristindalfopristin. ${ }^{5}$ Namun mengingat seringnya penggunaan antimikroba yang tidak rasional, tidak menutup kemungkinan dapat terjadi resistensi terhadap antibiotik tersebut di masa mendatang. ${ }^{1}$

Bakteri S. aureus dapat menimbulkan manifestasi klinis yang bervariasi. Infeksi bakteri ini dapat menyebabkan endokarditis, osteomyelitis akut, meningitis, hingga infeksi paru-paru. Toksin pada bakteri ini juga bisa menyebabkan sindrom yang disebut toxin shock syndrome, yang ditandai dengan demam tinggi, diare, muntah, myalgia, hingga gagal jantung dan gagal ginjal. ${ }^{1}$

Melihat kejadian resistensi yang semakin meningkat dan bahaya infeksi MRSA, perlu adanya alternatif pengobatan untuk menggantikan atau meningkatkan efektifitas kerja antimikroba dalam menghambat pertumbuhan bakteri $S$. aureus. ${ }^{6}$ Selada air (Nasturtium officinale) dilaporkan memiliki potensi antibakteri yang dapat digunakan sebagai solusi dari masalah tersebut. 7,8

Beberapa penelitian sebelumnya telah melakukan uji fitokimia untuk mengetahui kandungan ekstrak selada air. Ekstrak etanol daun selada air mengandung steroid atau triterpenoid, fenol hidrokuinon, alkaloid, ninhidrin, ${ }^{7}$ tannin, flavonoid, polifenolat, dan kuinon yang berperan dalam aktivitas antibakteri. ${ }^{8}$ Kandungan fitokimia pada bagian daun ini lebih banyak dibandingkan pada bagian batang yang hanya mengandung alkaloid, steroid, dan ninhidrin. ${ }^{7}$ Senyawa steroid dilaporkan mampu menghambat enzim gyrase dan topoisomerase IV yang berperan dalam sintesis DNA bakteri. ${ }^{9}$ Flavonoid bekerja dengan cara mengganggu proses sintesis asam nukleat, merusak membran sitoplasma dan mengganggu proses metabolisme bakteri. ${ }^{10}$ Tannin dapat berikatan dengan besi dan kalsium serta menghambat kerja enzim dan proses koagulasi plasma. ${ }^{11}$ Saponin dapat menyebabkan peningkatan permeabilitas sel dan kematian sel.12 Kandungan zat aktif dalam selada air juga dipengaruhi oleh jenis pelarut yang digunakan. Penelitian membuktikan bahwa ekstrak etanol selada air memiliki lebih banyak kandungan flavonoid, tannin, dan steroid dibandingkan selada air dalam bentuk serbuk maupun ekstrak air. ${ }^{13}$

Berdasarkan uraian di atas, ekstrak etanol daun selada air memiliki potensi untuk dimanfaatkan sebagai antibakteri, sehingga perlu diteliti aktivitasnya terhadap pertumbuhan MRSA secara in vitro. 


\section{Bahan dan Metode}

\section{Desain Penelitian}

Penelitian ini merupakan penelitian eksperimental laboratoris. Rancangan penelitian yang digunakan yaitu experimental post test only control group design dengan metode uji aktivitas antibakteri difusi sumuran.

\section{Sampel dan Kelompok Penelitian}

Bakteri MRSA didapat dari Laboratorium Mikrobiologi, Fakultas Kedokteran, Universitas Brawijaya adalah isolat klinik yang memiliki ciri-ciri Gram positif berbentuk kokus, tes katalase positif, tes koagulase positif, berwarna kuning pada mannitol salt agar, dan resisten terhadap sefoksitin pada metode difusi cakram (diameter zona hambat $\leq 21$ $\mathrm{mm}){ }^{14}$ Adapun daun selada air didapat dari UPT Laboratorium Herbal Materia Medica, Batu dan telah mendapatkan surat determinasi tanaman yang menyatakan bahwa sampel tersebut adalah daun selada air.

\section{Variabel Penelitian}

Variabel dependen yang digunakan yaitu diameter zona hambat yang diukur dengan penggaris dalam skala milimeter. Variabel independen yang digunakan adalah ekstrak etanol daun selada air (Nasturtium officinale) dengan enam konsentrasi yang berbeda, yaitu $0 \%$ sebagai kontrol negatif, $30 \%, 60 \%, 75 \%$, $90 \%$, dan $100 \%$.

\section{Ekstraksi Daun Selada Air (Nasturtium officinale)}

Daun selada air yang sudah dicuci bersih dan dipotong kecil-kecil dikeringkan pada suhu $40{ }^{\circ} \mathrm{C}$ selama 3 hari kemudian dihaluskan hingga mendapatkan simplisia. Ekstraksi simplisia dilakukan dengan metode maserasi dan evaporasi. Simplisia direndam di dalam etanol $96 \%$ dengan perbandingan $1: 4$ (1 kg bahan dalam 4 liter pelarut etanol) kemudian didiamkan pada suhu kamar selama 2×24 jam sambil sesekali diaduk hingga mengendap. Dari endapan ini, bagian filtrat yang terletak di bagian atas disaring lalu dimasukkan ke dalam erlenmeyer kemudian dilakukan remaserasi dengan cara direndam kembali pada larutan etanol $96 \%$ dan dibiarkan hingga mengendap. Hasil filtrat pertama sampai terakhir kemudian diuapkan dengan evaporator selama 2 jam untuk menghilangkan etanol. 15

\section{Identifikasi Bakteri Methicillin-Resistant Staphyloccus aureus (MRSA)}

Identifikasi bakteri yang dilakukan berupa pewarnaan Gram, tes katalase, tes koagulase, tes fermentasi mannitol pada media mannitol salt agar, dan tes sensitifitas sefoksitin. ${ }^{1}$ Bakteri dikatakan resisten terhadap sefoksitin apabila terbentuk zona hambat kurang atau sama dengan $21 \mathrm{~mm} .{ }^{14}$

\section{Uji Efektivitas Antibakteri}

Uji aktivitas antibakteri pada penelitian ini dilakukan dengan metode difusi sumuran. Peneliti menguji ektrak etanol daun selada air dengan enam konsentrasi yang berbeda, yaitu $30 \%, 60 \%, 75 \%, 90 \%$, dan $100 \%$ serta $0 \%$ sebagai kontrol negatif. Pengulangan setiap konsentrasi dilakukan sebanyak empat kali. Larutan Mueller-Hinton dan isolat bakteri MRSA dicampur pada cawan petri lalu tunggu hingga memadat. Kemudian media yang telah memadat dilubangi untuk membentuk sumur berdiameter $5 \mathrm{~mm}$ dan selanjutnya sumur diisi dengan ekstrak etanol daun selada air sebanyak $40 \mu \mathrm{l}$ dengan konsentrasi yang berbeda pada setiap sumuran. Selanjutnya, bakteri diinkubasi selama 18 hingga 24 jam pada suhu $37{ }^{\circ} \mathrm{C}$. Setelah proses inkubasi akan terbentuk zona hambat di sekitar sumuran. Zona hambat tersebut diukur menggunakan penggaris dalam skala millimeter $(\mathrm{mm})$ sebanyak 4 kali (secara horizontal, vertikal, dan 2 arah diagonal) kemudian diambil nilai rata-rata dari empat nilai hasil pengukuran. ${ }^{16}$ 
Semakin lebar diameter zona hambat, maka potensi antibakteri yang dimiliki ekstrak tersebut semakin besar. Hasil diameter zona hambat dapat dibagi dalam empat kategori aktivitas antibakteri, yaitu aktivitas lemah (diameter $<5 \mathrm{~mm}$ ), sedang (diameter 5-10 $\mathrm{mm}$ ), kuat (diameter 11-20 mm), dan sangat kuat (diameter $>20 \mathrm{~mm}$ ). ${ }^{17}$

\section{Analisis Data}

Analisis data secara statistik menggunakan uji normalitas dengan metode Saphiro Wilk untuk mengetahui distribusi data; uji homogenitas menggunakan metode Levene test untuk mengetahui homogenitas data; uji komparasi Kruskal Wallis untuk mengetahui adanya perbedaan yang signifikan antara diameter zona hambat pada beberapa kelompok konsentrasi ekstrak; uji post hoc Mann Whitney untuk mengetahui perbandingan data dari dua kelompok konsentrasi ekstrak; uji korelasi Spearmann untuk mengetahui kekuatan hubungan antara konsentrasi ekstrak dengan pertumbuhan bakteri MRSA; dan uji regresi untuk mengetahui besar pengaruh ekstrak terhadap zona hambat dan memprediksi nilai diameter

zona hambat dari sebuah persamaan khusus. ${ }^{18}$

Hasil

Hasil ekstraksi dengan metode maserasi dan evaporasi didapatkan ekstrak berwarna hijau pekat dengan konsistensi cair. Identifikasi bakteri didapatkan bakteri kokus Gram positif yang membentuk koloni seperti anggur, uji katalase dan koagulase positif, kemampuan fermentasi mannitol positif, dan bersifat resisten terhadap sefoksitin (zona hambat di sekitar cakram sefoksitin $30 \mu \mathrm{g}$ sebesar $11 \mathrm{~mm})$. Pada Gambar 1 ditampilkan aktivitas antibakteri ekstrak etanol daun selada air terhadap bakteri MRSA dengan berbagai konsentrasi.

Uji aktivitas antibakteri dilakukan menggunakan metode difusi sumuran dengan konsentrasi ekstrak etanol daun selada air $30 \%, 60 \%, 75 \%$, $90 \%$, 100\%, dan $0 \%$ sebagai kontrol negatif. Hasil menunjukkan adanya perbedaan lebar diameter zona hambat pertumbuhan bakteri MRSA pada setiap konsentrasi (Gambar 1).

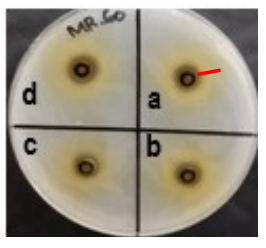

$60 \%$

$100 \%$

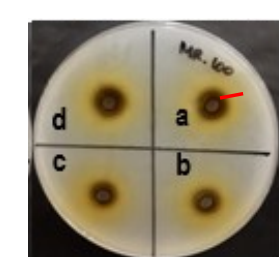

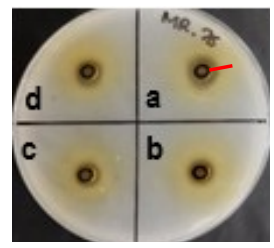

$75 \%$

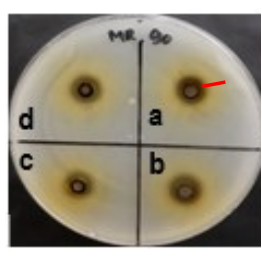

$90 \%$

Gambar 1. Aktivitas antibakteri ekstrak etanol daun selada air (Nasturtium officinale) terhadap bakteri MRSA dengan metode difusi sumuran yang ditunjukkan dengan garis merah $(-)$ Keterangan: a) pengulangan ke-1, b) pengulangan ke-2, c) pengulangan ke-3, d) pengulangan ke-4 
Tabel 1. Diameter zona hambat pertumbuhan bakteri MRSA pada konsentrasi ekstrak etanol daun selada air yang berbeda

\begin{tabular}{|c|c|c|c|c|c|c|}
\hline \multirow{2}{*}{$\begin{array}{l}\text { Konsentrasi Ekstrak } \\
(\%)\end{array}$} & \multicolumn{4}{|c|}{$\begin{array}{l}\text { Diameter Zona Hambat pada } \\
\text { Pengulangan ke- }(\mathrm{mm})\end{array}$} & \multirow{2}{*}{ Rata-rata $(\mathrm{mm}) \pm \mathrm{SD}$} & \multirow[t]{2}{*}{$p$} \\
\hline & 1 & 2 & 3 & 4 & & \\
\hline 0 & - & - & - & - & - & \\
\hline 30 & 6,25 & 6 & 6,125 & 6,25 & $6,16 \pm 0,12$ & $0,013^{*}$ \\
\hline $\begin{array}{l}60 \\
75 \\
90\end{array}$ & $\begin{array}{c}7,25 \\
8,5 \\
9,25\end{array}$ & $\begin{array}{l}7,25 \\
7,125 \\
8,875\end{array}$ & $\begin{array}{c}7 \\
7,75 \\
8,75\end{array}$ & $\begin{array}{c}7,25 \\
8,25 \\
9\end{array}$ & $\begin{array}{l}7,19 \pm 0,13 \\
7,90 \pm 0,61 \\
8,97 \pm 0,21\end{array}$ & $\begin{array}{l}0,011^{*} \\
0,014^{*} \\
0,014^{*}\end{array}$ \\
\hline 100 & 9,875 & 10,25 & 9,625 & 9,75 & $9,88 \pm 0,21$ & $0,014^{*}$ \\
\hline
\end{tabular}

Keterangan: $\left(^{*}\right)$ signifikan $p<0,05$

Selain itu, diketahui bahwa semakin tinggi konsentrasi ekstrak etanol daun selada air, maka diameter zona hambat yang terbentuk semakin lebar (Tabel 1). Berdasarkan Tabel 1, zona hambat mulai terlihat pada konsentrasi $30 \%$ dengan ratarata 6,16 $\mathrm{mm}$ (aktivitas antibakteri sedang). Zona hambat terbesar terlihat pada kelompok konsentrasi $100 \%$ dengan diameter rata-rata $9,88 \mathrm{~mm}$ (aktivitas antibakteri sedang). Pada kontrol negatif (konsentrasi ekstrak $0 \%$ ) berupa pemberian akuades tidak didapatkan zona hambat di sekitar lubang sumuran. Maka, dapat disimpulkan adanya peningkatan lebar diameter zona hambat seiring dengan peningkatan konsentrasi ekstrak etanol daun selada air.

\section{Analisis Data}

Uji normalitas dengan metode Shapiro Wilk menunjukkan bahwa seluruh kelompok memiliki distribusi normal $(p>0,05)$, kecuali kelompok konsentrasi ekstrak $60 \%$ ( $p=$ 0,001). Uji homogenitas dengan uji Levene didapatkan variasi data diameter zona hambat pertumbuhan bakteri MRSA dari setiap konsentrasi tidak homogen $(p<0,05)$. Data pada penelitian ini tidak homogen sehingga analisis statistik dilakukan menggunakan uji nonparametrik berupa uji komparasi Kruskal Wallis, uji post hoc Mann Whitney, uji korelasi Spearmann, dan uji regresi. ${ }^{18}$
Hasil uji komparasi Kruskal Wallis menunjukkan perbedaan yang signifikan antara diameter zona hambat pertumbuhan bakteri MRSA pada beberapa kelompok konsentrasi ekstrak $(p<0,05)$. Uji post hoc Mann Whitney menunjukkan adanya perbedaan data antar kelompok yang signifikan $(p<0,05)$, kecuali kelompok $60 \%$ dan $70 \%(p=0,20)$. Uji korelasi Spearman menunjukkan adanya hubungan yang signifikan antara perbedaan konsentrasi ekstrak dan diameter zona hambat $(p<0,05)$ dengan arah korelasi positif dan kekuatan korelasi yang sangat kuat $(r=0,979)$. Dengan kata lain, pemberian konsentrasi ekstrak yang tinggi akan memberikan hasil diameter zona hambat yang lebar. Sebaliknya, pemberian konsentrasi ekstrak yang rendah akan memberikan hasil diameter zona hambat yang sempit. Hasil uji regresi menunjukkan nilai $R$ square sebesar 0,945 dengan nilai signifikansi $0,00(p<0,05)$.

Dengan kata lain, terdapat $94,5 \%$ kemungkinan bahwa zona hambat yang terbentuk di-pengaruhi oleh pemberian ekstrak etanol daun selada air dan 5,5\% kemungkinan bahwa zona hambat dapat disebabkan oleh variabel yang tidak diukur dalam penelitian ini dan mem-pengaruhi hasil penelitian. Hubungan antara peningkatan konsentrasi ekstrak etanol daun selada air terhadap besar diameter zona hambat dapat dinyatakan dengan rumus $Y=4,766+0,46 X$ dengan $Y$ merupakan besar diameter zona 
hambat dan $\mathrm{X}$ merupakan nilai konsentrasi ekstrak etanol daun selada air. ${ }^{18}$

\section{Pembahasan}

Penelitian ini bertujuan untuk mengetahui aktivitas antibakteri ekstrak etanol daun selada air (Nasturtium officinale) terhadap bakteri methicillin-resistant Staphylococcus aureus (MRSA) secara in vitro. Penelitian pendahuluan dilakukan menggunakan konsentrasi ekstrak $0 \%, 5 \%$, $10 \%, 15 \%, 20 \%, 25 \%, 30 \%, 35 \%, 40 \%, 45 \%$, $50 \%, 55 \%, 60 \%, 65 \%, 70 \%, 75 \%, 80 \%, 85 \%$, $90 \%, 95 \%$ dan $100 \%$. Berdasarkan hasil penelitian pendahuluan, konsentrasi ekstrak yang digunakan pada penelitian inti yaitu $100 \%, 90 \%, 75 \%, 60 \%$, dan $30 \%$ serta kontrol negatif berupa pemberian akuades (konsentrasi ekstrak 0\%) dengan pengulangan masing-masing konsentrasi sebanyak empat kali. Diameter zona hambat sebagai hasil penelitian diukur menggunakan penggaris dalam skala millimeter. Diameter zona hambat yang lebar menunjukkan aktivitas antibakteri ekstrak yang tinggi. Sebaliknya, diameter zona hambat yang kecil menunjukkan aktivitas antibakteri ekstrak yang rendah. ${ }^{17}$

Ekstraksi daun selada air dilakukan dengan metode maserasi dan evaporasi. Peneliti menggunakan pelarut etanol $96 \%$ karena aktivitas antibakteri pada ekstrak etanol lebih tinggi daripada ekstrak dengan pelarut air. Selain itu, etanol memiliki kelarutan yang lebih tinggi sehingga zat aktif di dalam daun selada air lebih mudah larut di dalam cairan etanol. ${ }^{19}$ Namun, aktivitas antibakteri tidak dipengaruhi oleh pelarut etanol karena dilakukan evaporasi yang bertujuan untuk menghilangkan pelarut sehingga dapat dikatakan bahwa pada ekstrak ini seluruh pelarut etanol sudah menguap. ${ }^{12}$

Pada hasil penelitian, didapatkan hasil rata-rata besar diameter zona hambat pada konsentrasi $30 \%$ sebesar $6,16 \mathrm{~mm}$, konsentrasi $60 \%$ sebesar $7,19 \mathrm{~mm}$, konsentrasi $75 \%$ sebesar $7,90 \mathrm{~mm}$, konsentrasi $90 \%$ sebesar $8,97 \mathrm{~mm}$, dan konsentrasi $100 \%$ sebesar $9,88 \mathrm{~mm}$. Hasil ini menunjukkan bahwa semakin tinggi konsentrasi ekstrak yang diberikan, maka semakin besar diameter zona hambat pertumbuhan bakteri MRSA yang terbentuk ( $p$ $<0,05)$.

Hambatan pada pertumbuhan MRSA disebabkan oleh beberapa senyawa aktif yang ada di dalam ekstrak etanol daun selada air yaitu flavonoid, tannin, saponin, dan steroid yang dilaporkan berperan sebagai antibakteri. ${ }^{20}$ Flavonoid bekerja dengan cara mengganggu proses metabolisme bakteri, menurunkan fungsi membran sitoplasma, dan menghambat sintesis asam nukleat bakteri. ${ }^{10}$ Tannin dapat menginaktivasi enzim intrasel, menghambat koagulasi plasma, dan mengikat besi dan kalsium yang diperlukan tubuh. ${ }^{11}$ Saponin dapat meningkatkan permeabilitas sel sehingga menyebabkan terjadinya kematian sel. ${ }^{12}$ Mekanisme kerja steroid yaitu dengan cara menghambat enzim DNA gyrase dan topoisomerase IV yang berperan dalam sintesis DNA bakteri. ${ }^{9}$

Penelitian mengenai aktivitas antibakteri daun selada air terhadap beberapa bakteri lain sudah pernah dilakukan. Bakteri Gram positif (Staphylococcus aureus dan Listeria monocytogenes) lebih sensitif terhadap pemberian ekstrak etanol selada air dibandingkan bakteri Gram negatif (Escherichia coli dan Salmonella Typhimurium). Hal ini disebabkan zat aktif steroid, flavonoid, dan saponin pada selada air bersifat hidrofobik sedangkan bakteri Gram negatif memiliki membran luar yang terdiri atas lipopolisakarida yang berfungsi sebagai barier terhadap molekul hidrofobik sehingga zat aktif tersebut sulit masuk ke dalam sel bakteri. ${ }^{19}$ Pemberian ekstrak metanol daun selada air dikombinasikan dengan antibiotik gentamisin memberikan pengaruh yang signifikan 
terhadap diameter zona hambat dan mampu membentuk diameter zona hambat yang lebih besar $(20,3 \mathrm{~mm})$ dibandingkan pemberian antibiotik saja $(17,7 \quad \mathrm{~mm}){ }^{21}$ Hal ini menunjukkan bahwa ekstrak daun selada air memberikan efek sinergis terhadap antibiotik. Ekstrak etanol selada air juga memiliki aktivitas antibakteri terhadap Propionibacterium acnes dengan diameter zona hambat mulai $13,25 \mathrm{~mm}$ hingga 16 $\mathrm{mm} .{ }^{8}$ Dari ketiga studi ini, dapat dinyatakan bahwa ekstrak etanol daun selada air memiliki aktivitas antibakteri yang dapat menghambat pertumbuhan bakteri Gram positif. $8,19,21$

Penelitian lain telah dilakukan untuk menguji potensi ekstrak etanol buah belimbing wuluh (Averrhoa bilimbi Linn) yang dapat menghambat pertumbuhan MRSA pada konsentrasi $50 \%$ dengan rata-rata diameter zona hambat sebesar $24,375 \mathrm{~mm} .{ }^{22}$ Hasil ini menunjukkan diameter zona hambat yang lebih besar karena sumuran yang dibuat berdiameter $6 \mathrm{~mm}$. Ekstrak etanol bunga cengkeh (Syzygium aromaticum) memiliki aktivitas antibakteri terhadap bakteri MRSA dengan Kadar Bunuh Minimal (KBM) pada konsentrasi $0,39 \%$ dan Kadar Hambat Minimal (KHM) yang tidak dapat dianalisis karena kekeruhan warna ekstrak. ${ }^{23}$ Dari kedua studi ini diketahui bahwa ekstrak etanol daun selada air memiliki potensi antibakteri yang lebih lemah dibandingkan ekstrak etanol buah belimbing wuluh dan bunga cengkeh terhadap bakteri MRSA. Hal ini disebabkan oleh perbedaan kadar dan kandungan senyawa aktif pada ketiga tanaman serta perbedaan metode dan prosedur uji aktivitas antibakteri yang dilakukan.22,23

Pada studi ini, uji aktivitas antibakteri dilakukan dengan metode difusi sumuran. Metode ini hanya mengukur besar diameter zona hambat pertumbuhan bakteri pada nilai konsentrasi ekstrak yang berbeda. Kekurangan metode ini yaitu tidak dapat mengukur Kadar Hambat Minimal (KHM) dan Kadar Bunuh Minimal (KBM). ${ }^{14}$ Oleh karena itu, perlu dilakukan studi lanjutan dengan metode dilusi tabung yang dapat menentukan KHM dan KBM atau metode in vivo yang dapat menentukan dosis efektif, efek samping, serta dosis dan efek toksik ekstrak etanol daun selada air. ${ }^{14}$ Penelitian ini diharapkan dapat menjadi dasar bagi penelitian selanjutnya mengenai ekstrak etanol daun selada air sebelum dimanfaatkan secara klinis sebagai salah satu terapi alternatif penyakit infeksi yang disebabkan oleh MRSA sehingga dapat mencegah kejadian resistensi terhadap antibiotik dan menurunkan morbiditas penyakit infeksi akibat MRSA.

Pada penelitian ini, penulis tidak melakukan pengukuran kadar masing-masing senyawa aktif yang terkandung pada ekstrak etanol daun selada air yang berperan sebagai antibakteri. Selain itu, hasil penelitian tidak dibandingkan dengan antibiotik lini pertama pada infeksi MRSA yaitu vankomisin. Peneliti juga tidak mengukur dan menganalisis faktor-faktor yang dapat menurunkan aktivitas antibakteri pada ekstrak seperti lama dan suhu penyimpanan ekstrak. Oleh karena itu, diperlukan studi lanjutan yang dapat membandingkan hasil penelitian dengan antibiotik lini pertama pada pengobatan infeksi MRSA, mengetahui kadar kandungan zat aktif pada daun selada air, dan mengetahui pengaruh suhu dan lama waktu penyimpanan ekstrak terhadap diameter zona hambat.

\section{Kesimpulan}

Kesimpulan penelitian ini adalah ekstrak etanol daun selada air (Nasturtium officinale) memiliki aktivitas antibakteri yang mampu menghambat pertumbuhan MRSA secara in vitro dengan metode difusi sumuran pada konsentrasi ekstrak 30\%, 60\%,75\%, 90\% dan $100 \%$. 
Selain itu, semakin tinggi konsentrasi ekstrak etanol daun selada air yang diberikan maka semakin lebar diameter zona hambat pertumbuhan bakteri MRSA.

\section{Daftar Pustaka}

1. Caroll KC, Morse $S A$, Mietzner $T$, dan Miller S. Jawetz, Melnick \& Adelberg's Medical Microbiology. 27 th edition. New York: McGraw-Hill Education. 2016.

2. Nismawati, Sjahril R, dan Agus R. Deteksi Methicillin-Resistant Staphylococcus aureus pada Pasien Rumah Sakit Universitas Hasanuddin dengan Metode Kultur. Prosiding Seminar Nasional Megabiodiversitas Indonesia. 2018; 3(7):15-21.

3. Chen CJ \& Huang YC. New Epidemiology of Staphyloccus aureus infection in Asia. Clinical Microbiology and Infection. 2014; (20)7:605-623.

4. Erikawati D, Santosaningsih D, dan Santoso S. Tingginya Prevalensi MRSA pada Isolat Klinik Periode 2010-2014 di RSUD Dr. Saiful Anwar Malang, Indonesia. Jurnal Kedokteran Brawijaya. 2016; 29(2):149-156.

5. Katzung BG, Masters SB, dan Trevor AJ (Editor). Farmakologi Dasar \& Klinik Edisi ke-12. New York: Mc Graw-Hill Education. 2012.

6. Nursidika P, Saptarini O, Rafiqua N. Aktivitas Antimikroba Fraksi Ekstrak Etanol Buah Pinang (Areca catechu L) pada Bakteri Methicillin Resistant Staphylococcus aureus. Majalah Kedokteran Bandung. 2014; 46(2):94-99.

7. Salamah E, Purwaningsih $S$, dan Permatasari E. Aktivitas Antioksidan dan Komponen Bioaktif pada Selada Air (Nasturtium officinale L. R. Br). Jurnal
Pengolahan Hasil Perikanan Indonesia. 2011; 15(2);85-91.

8. Yuliawati $\mathrm{K}$, Rismawati $\mathrm{E}$, dan Dasuki U. Pengujian Aktivitas Antibakteri Ekstrak Etanol Selada Air dan Pohpohan terhadap Propionibacterium acnes. Prosiding Seminar Nasional Nasional Penelitian dan PKM Kesehatan. 2016; 6:244-233.

9. Nadaraia NS. Amiranashvili LS, Merlain M, Karkhabrishvili ML, Barbakadze NN, Geronikaki A, Petrou A, Poroikov V, Ciric A, Glamoclija J, Sokovic M. Novel Antimicrobial Agents; Discovery Among the Steroid Derivatives. Steroids. 2019; 144:1-37.

10.Cushnie $T$ \& Lamb A. Antimicrobial Activity of Flavonoids. International Journal of Antimicrobial Agents. 2005; 26 (5):343-356.

11. Akiyama $H$, Kazuyasu $F$, Yamasaki $O$, Oono T, dan Iwatsuki K. Antibacterial Action of Several Tannins Against Staphylococcus aureus. J of Antimicrobial Chemotherapy. 2001; 48(1):487-491.

12. Hossain MT, Asadujjaman, Imran N, Matin A, Chowdhury R, dan Rashid H. A Study on the Pharmacological Effects and Mechanism of Action of Alkaloids, Glycosides, and Saponins. The Pharmaceutical and Chemical Journal. 2019; 6(2):112-122.

13. Rahman DR, Rimbawan, Madanijah S, Purwaningsih S. Potensi Selada Air (Nasturtium Officinale R. Br) Sebagai Antioksidan dan Agen Antiproliferasi terhadap Sel MCF-7 secara In Vitro. J. Gizi Pangan. 2017; 12(3):217-224.

14.CLSI. M100S Perfomance Standards for Antimicrobial Susceptibility Testing $26^{\text {th }}$ edition. Pennsylvania: Clinical and Laboratory Standards Institute. 2016. 
15. Nugroho A. Buku Ajar Teknologi Bahan Alam. Banjarmasin: Lambung Mangkurat University Press. 2017.

16. Balouiri M, Sadiki M, \& Ibnsouda SK. Methods for In Vitro Evaluating Antimicrobial Activity: A Review. Journal of Pharmaceutical Analysis. 2016; 6 (2):71-79.

17. Davis WW \& Stout TR. Disc Plate Method of Microbiological Antibiotic Assay. Applied and Enviromental Microbiology. 1971; 22(4):666-670.

18. Sugiyono. Statistika untuk Penelitian. Bandung: Alfabeta. 2013.

19. Derhami SF, Rad MG, Mahmoudi R. Evaluation of Antibacterial Effects of Aqueous and Alcoholic Extracts of Nasturtium officinale on Some Pathogenic. Medical Laboratory Journal. 2016; 10(6):49-53.

20. Harmita dan Radji M. Kepekaan terhadap Antibiotik. Dalam: Buku Ajar Analisis Hayati. Edisi ke-3. Jakarta: EGC. 2008.
21. Freitas E, Aires A, Rosa EA, Saavedra MJ. Antibacterial Activity and Synergistic Effect between Watercress Extracts, 2Phenylethyl Isothiocyanate and Antibiotic Against 11 Isolates of Escherichia coli from Clinical and Animal Source. Letters in Applied Microbiology. 2013; 57(4):266273.

22. Chandra RA, Yunita R, Wahyuni DD, Anggraini DR. Daya Antibakteri Ekstrak Buah Belimbing Wuluh (Averrhoa bilimbi Linn) terhadap Methicillin-resistant Staphylococcus aureus. Essence of Scientific Medical Journal. 2018; 16(1):43 $-47$

23. Azizah A, Suswati I, Agustin SM. Efek Antimikroba Ekstrak Bunga Cengkeh (Syzygium aromaticum) terhadap Methicillin-resistant Staphylococcus aureus (MRSA) Secara In Vitro. Saintika Medika: Jurnal IImu Kesehatan dan Kedokteran Keluarga. 2017; 13(1):31-35. 